\title{
Calcination Behaviour of Nsuta Rhodochrosite Ore in the Presence and Absence of End-of-Life High Density Polyethylene*
}

\author{
${ }^{1}$ K. O. Nimako, ${ }^{1}$ A. Dwumfour, ${ }^{2}$ K. Mensah, ${ }^{3}$ P. Koshy and ${ }^{1}$ J. R. Dankwah \\ ${ }^{1}$ University of Mines and Technology, Tarkwa, Ghana \\ ${ }^{2}$ Egypt-Japan University of Science and Technology, Alexandria, Egypt \\ ${ }^{3}$ University of New South Wales, Sydney, Australia
}

Nimako, K. O., Dwumfour, A., Mensah, K., Koshy, P. and Dankwah, J. R. (2020), "Calcination Behaviour of Nsuta Rhodochrosite Ore in the Presence and Absence of End-of-Life High Density Polyethylene", Ghana Mining Journal, Vol. 20, No. 2, pp. 27-35.

\begin{abstract}
This research investigated the calcination behaviour of the Nsuta Rhodochrosite $\left(\mathrm{MnCO}_{3}\right)$ in the presence and absence of end-of-life high density polyethylene (HDPE) using a custom-made palm kernel shell fired furnace. Samples of pulverised Nsuta rhodochrosite were heated rapidly for 30,40, 50 and 60 minutes, coupled with temperature measurements to determine the maximum temperature attained in the fireclay crucible. The procedure at 60 min was repeated using three blends of rhodochrosite samples containing different masses of HDPE (30 g, $40 \mathrm{~g}$ and $50 \mathrm{~g})$ and heated for an hour. For gas analyses studies during calcination, cylindrical compacts of rhodochrosite ore in a LECO ${ }^{\mathrm{TM}}$ crucible were heated rapidly with and without high density polyethylene (HDPE at C/O ratio $=1.0,1.5$, and 2.0) in a horizontal tube furnace for $600 \mathrm{~s}$ at $1150{ }^{\circ} \mathrm{C}$ under high purity argon gas and the off gas was continuously analysed for $\mathrm{CH}_{4}, \mathrm{CO}$ and $\mathrm{CO}_{2}$ using an online infrared gas analyser. The content of $\mathrm{H}_{2}$ in the off gas was detected using a $\mathrm{GC} 3$ gas chromatographic analyser equipped with a thermal conductivity detector. The Nsuta rhodochrosite ore was found to consist of a mixture of manganese II carbonate $\left(\mathrm{MnCO}_{3}\right)$, silica $\left(\mathrm{SiO}_{2}\right)$, mixed transition metal carbonate of the form $\mathrm{Ca}(\mathrm{Mn}, \mathrm{Mg})\left(\mathrm{CO}_{3}\right)_{2}$ and mixed metal silicate of the form $\mathrm{Ca}_{0.6} \mathrm{Mg}_{1.94} \mathrm{Si}_{2} \mathrm{O}_{6}$. Calcination results indicated visible colour changes (from grey to dark brown), along with significant changes in the mass before and after calcination. In the absence and presence of the polymer, measured temperatures in the crucible ranged from $1001{ }^{\circ} \mathrm{C}$ to $1366{ }^{\circ} \mathrm{C}$ and $1361{ }^{\circ} \mathrm{C}$ to $1369{ }^{\circ} \mathrm{C}$, respectively. Analyses by XRF showed marginal increase in the content of $\mathrm{Mn}$ in the calcined ore with HDPE addition. Gas analyses indicate that blending the carbonate with HDPE before heating results in significant decrease in the amount of $\mathrm{CO}_{2}$ emitted.
\end{abstract}

Keywords: Land Tenure Security, Registration, Spatial Data, Attribute Data

\section{Introduction}

The Nsuta Manganese Mine is located on latitude $5^{\circ} 16^{\prime} 59^{\prime \prime}$ North and longitude $1^{\circ} 58^{\prime} 0^{\prime \prime}$ West in the Western Region of Ghana. Although the mine has produced oxide ore for a number of years, such production is no longer sustainable due to the depletion of the oxide ore (Ali and Amankwah, 2013). As such, production is now fully on the manganese carbonate (averaging 34.16\% Mn (Kesse, 1985)) which is close to metallurgical grade of 38 - 55\% Mn (Ali and Amankwah, 2013). The conversion of manganese carbonate to oxide is usually by calcination (Amankwah and Pickles 2005; Dankwah 2014) and may follow the following reactions, depending on the furnace environment:

$$
\begin{aligned}
& \mathrm{MnCO}_{3}=\mathrm{MnO}+\mathrm{CO}_{2} \\
& 3 \mathrm{MnCO}_{3}=\mathrm{Mn}_{3} \mathrm{O}_{4}+2 \mathrm{CO}_{2}+\mathrm{CO}
\end{aligned}
$$

From equations (1) and (2) the equilibrium constants $\left(\mathrm{k}_{\mathrm{p}}\right)$ for the calcination process (assuming pure solid species) are related to the partial pressures of gaseous species $\left(\mathrm{CO}\right.$ and $\mathrm{CO}_{2}$, i.e. pCO and $\mathrm{pCO}_{2}$ ) as follows:

$k_{p_{1}}=p \mathrm{CO}_{2}$

$$
k_{p_{2}}=\left(p C O_{2}\right)^{2} \cdot p C O
$$

In another development, a study conducted by O'Shaughnessy et al. (2004) concluded that Nsuta manganese carbonate is still acceptable in its nature for manganese ferroalloy production. The thermal decomposition of metal carbonates and or hydroxides have been investigated before (Borgwardt, 1985; Chen et al., 2009; Kim and Kwon, 1998; Li et al., 2005; Samtani et al., 2002; Telfer et al., 2000; Wang et al., 2007; Yamaguchi et al., 1980). The effect of $\mathrm{CO}_{2}$ partial pressure on the thermal decomposition kinetics of metal carbonates such as $\mathrm{CdCO}_{3}, \mathrm{MnCO}_{3}, \mathrm{PbCO}_{3}$ and $\mathrm{ZnCO}_{3}$ were investigated by Criado et al., 1998; Criado et al., 1987; Criado et al., 1982; Yamada et al., 2009; Yamaguchi et al., 1980). In all these investigations no polymers were added and, accordingly, there was no investigation on the effect of gases from the thermal decomposition of polymers. The addition of a polymer to metal reduction processes is thought to have an attenuating effect on especially the $\mathrm{CO}_{2}$ that is evolved into the atmosphere (Dankwah et al., 2011; Dankwah et al., 2012; Dankwah et al., 2013).

Dankwah (2014) investigated the effect of HDPE and linear low density polyethylene (LLDPE) on $\mathrm{CO}_{2}$ emissions during the calcination of reagent 
grade $\mathrm{MnCO}_{3}$. Using a horizontal tube furnace at various $\mathrm{C} / \mathrm{O}$ ratios, they observed that the presence of a polymer has a significant attenuating effect on $\mathrm{CO}_{2}$ emissions. It was further reported that the observed attenuation of $\mathrm{CO}_{2}$ emissions was accompanied by a simultaneous production of syngas $\left(\mathrm{CO}+\mathrm{H}_{2}\right)$ that could be recovered as a beneficial by-product

The aim of this investigation is therefore to establish a fundamental understanding of the calcination behaviour of the Nsuta carbonate ore in the absence and presence of waste plastics.

\section{Resources and Methods Used}

\subsection{Materials}

Pulverised samples $(-75 \mu \mathrm{m})$ of naturally occurring rhodochrosite ore from Nsuta (Fig. 1), Ghana was used for this experimental investigation as a source of $\mathrm{MnCO}_{3}$, whilst samples of pure water sachets (PWS) collected from the university of Mines and Technology, Tarkwa were used as the source of reductant.

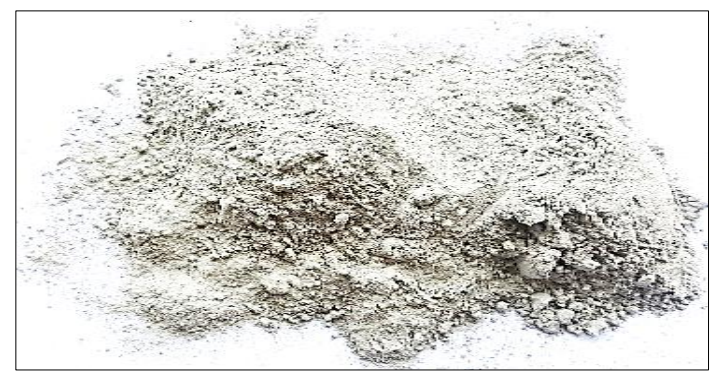

Fig. 1 Pulverised Nsuta Rhodochrosite

Samples of HDPE were subjected to a meltingquenching process (Fig. 2) to render them brittle, followed by milling in a laboratory ball mill to obtain pulverised carbonaceous reductant as shown in Fig. 3.

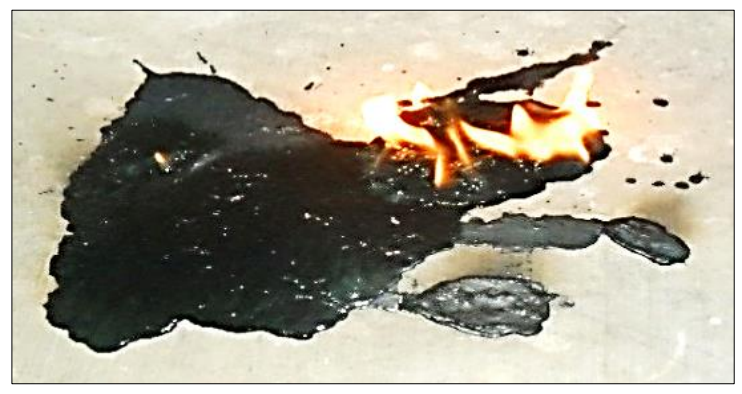

Fig. 2 Formation of Embrittled HDPE after a Melting-Quenching Process

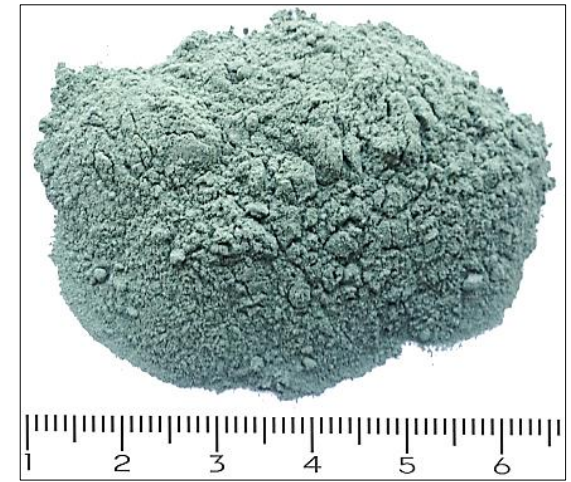

Fig. 3 Samples of Pulverised Carbonaceous Material obtained from Heat-treated HDPE

\subsection{Experimental Procedure}

\subsubsection{Calcination of Nsuta Rhodochrosite Ore}

About $50 \mathrm{~g}$ of pulverised Nsuta Rhodochrosite ore was placed in a fireclay crucible and calcined for 40 minutes in a charred palm kernel shell fired furnace (Fig. 4). The calcined sample was quickly withdrawn from the furnace and the temperature was recorded using a K-type thermocouple; the calcined sample was then allowed to cool and its mass measured and recorded using an electronic balance. This procedure was repeated three times after which the calcined samples were crushed, ground and sieved to $-75 \mu \mathrm{m}$.

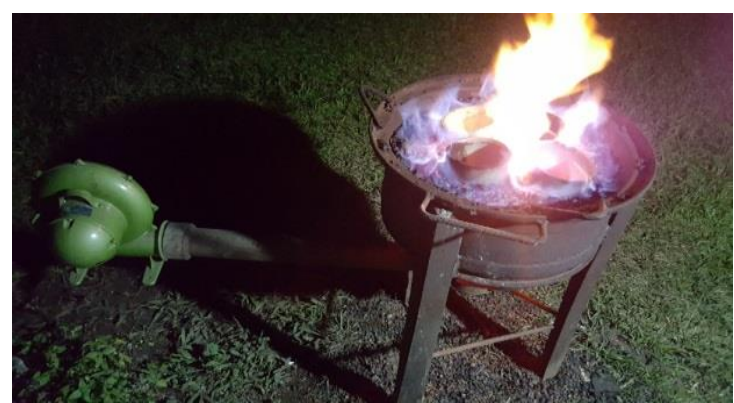

Fig. 3 Firing of Crucibles containing Samples

\subsubsection{Calcination of Nsuta Rhodochrosite Ore in Horizontal Tube Furnace (Gas Measurements)}

About $2.0 \mathrm{~g}$ of the ore was compacted in a die to produce cylindrical pellets $(\sim 1.2 \mathrm{~mm}$ thick and 15 mm diameter) (Fig. 5), by applying a load of 7.5 tonnes for 2 minutes in a hydraulic press. Each cylindrical pellet was placed in $\mathrm{LECO}^{\mathrm{TM}}$ crucible and the sample assembly was placed in the cold zone of an electrically heated horizontal tube furnace (Fig 6), which was purged continuously with argon (of $99.995 \%$ purity and flow rate 1.0 $\mathrm{L} / \mathrm{min}$ ) to ensure inert conditions. 
The content of $\mathrm{H}_{2}$ in the offgas was detected by a gas chromatographic (GC3) analyser equipped with a thermal conductivity detector (TCD). The TCD detector responds to the difference between the thermal conductivity of the carrier gas and the analyte peak; the greater the difference in thermal conductivity the better the sensitivity. Argon ( $\kappa$ =39) was used as the carrier gas as the target analyte peak was hydrogen $(\kappa=419)$. The other gases, $\mathrm{CO}(\kappa=53), \mathrm{CO}_{2}(\kappa=34)$ and $\mathrm{CH}_{4}(\kappa=73)$ were measured quantitatively using an IR-gas analyser. Peak determination of these gases on the chromatogram was not satisfactory since their thermal conductivities were close to the carrier gas (argon).

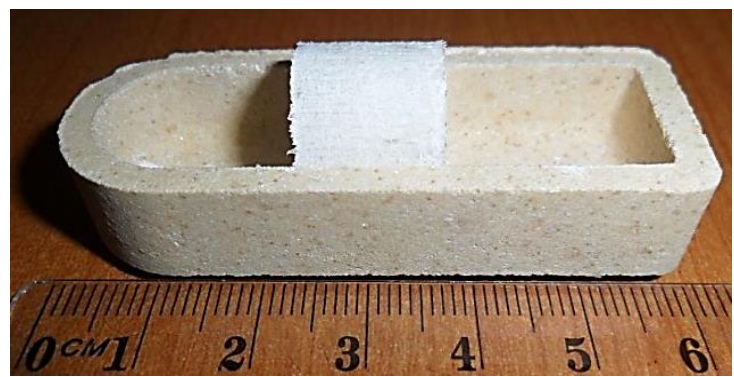

Fig. 5 Cylindrical Pellet of Nsuta Rhodochrosite Ore in a LECO $^{\mathrm{TM}}$ Crucible

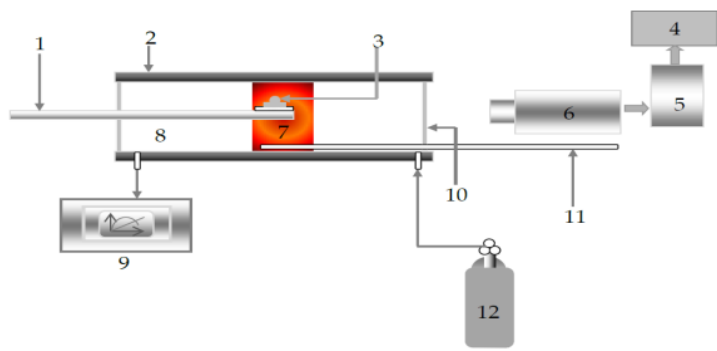

Fig. 6 Schematic of the horizontal tube furnace and IR gas analyser system (1 Sample Rod; 2 Alumina tube; 3 Reaction mixture; 4 PC; 5 DVD; 6 CCD Camera; 7 Hot Zone; 8 Cold Zone; 9 Gas analyser; 10 Quartz window; 11 Thermocouple; 12 Argon gas)

After the furnace had attained the desired hot zone temperature $\left(1150{ }^{\circ} \mathrm{C}\right)$, the sample was pushed in the reaction hot zone and gases $\left(\mathrm{CH}_{4}, \mathrm{CO}\right.$ and $\left.\mathrm{CO}_{2}\right)$ were monitored for $900 \mathrm{~s}$ by an infrared gas analyser attached to the system; the results were recorded in a data-logging computer.

\section{Results and Discussion}

\subsection{Nature of Nsuta Rhodochrosite Ore}

3.1.1 Results of XRD, XRF, SEM/EDS Analyses of Nsuta Rhodochrosite

Fig. 7 shows the X-Ray diffraction patterns of pulverised samples of as-received Nsuta
Rhodochrosite ore. Well defined peaks of $\mathrm{MnCO}_{3}$ can be seen along with peaks of $\mathrm{SiO}_{2}, \mathrm{Ca}(\mathrm{Mn}$, $\mathrm{Mg})\left(\mathrm{CO}_{3}\right)_{2}$ and $\mathrm{Ca}_{0.6} \mathrm{Mg}_{1.94} \mathrm{Si}_{2} \mathrm{O}_{6}$. The XRF results are shown in Table 1. It is clear from Table 1 that $\mathrm{MnO}$ is the major component and as would be expected $\mathrm{SiO}_{2}, \mathrm{CaO}$ and $\mathrm{MgO}$ are also present. The silica content of this ore is above $10 \mathrm{wt} \%$, making it suitable for the production of silicomanganese, unless the ore can be upgraded to decrease the content of $\mathrm{SiO}_{2}$. A desirable future of this ore is the phosphorous content which is below $0.1 \mathrm{wt} \%$. The content of phosphorous in a manganese ore is critical and must typically be kept below $0.1 \mathrm{wt} \%$ as it cannot be removed during processing and accordingly end up in the final product to cause problems.

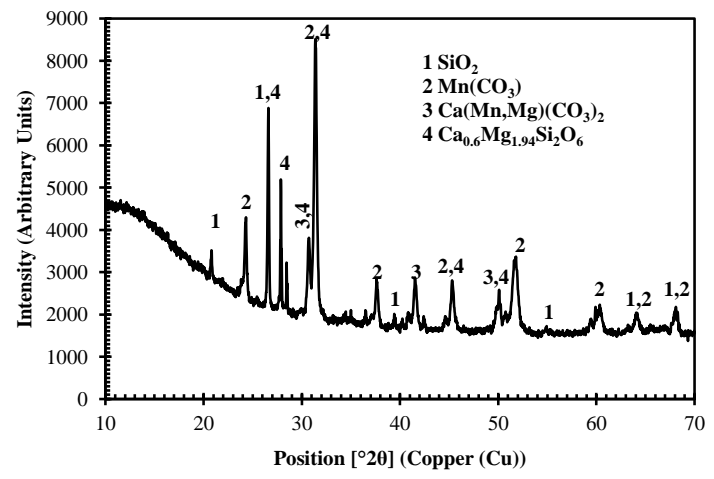

Fig. 7 X-Ray Diffractogram (XRD) of Nsuta Rhodochrosite Ore utilised for the Investigation

Table 1 XRF of Pulverised Rhodochrosite Ore.

\begin{tabular}{lccccc}
\hline Component & $\mathrm{SiO}_{2}$ & $\mathrm{Al}_{2} \mathrm{O}_{3}$ & $\mathrm{MgO}$ & $\mathrm{MnO}$ & $\mathrm{TiO}_{2}$ \\
\hline wt $\%$ & 15.02 & 2.20 & 4.98 & 39.30 & 0.03 \\
\hline Component & $\mathrm{Na}_{2} \mathrm{O}$ & $\mathrm{P}_{2} \mathrm{O}_{5}$ & $\mathrm{~V}_{2} \mathrm{O}_{5}$ & $\mathrm{CaO}$ & $\mathrm{NiO}$ \\
\hline wt $\%$ & 0.66 & 0.08 & 0.03 & 5.91 & 0.03 \\
Component & $\mathrm{Fe}_{2} \mathrm{O}_{3}$ & $\mathrm{~K}_{2} \mathrm{O}$ & $\mathrm{SO}_{3}$ & $\mathrm{ZnO}$ & $\mathrm{LOI}$ \\
wt $\%$ & 1.24 & 0.28 & 0.44 & 0.01 & 29.80 \\
\hline
\end{tabular}

Results of the SEM of the ore at two different magnifications $(\times 500$ and $\times 2.0 \mathrm{k})$ are shown in Fig. $8 \mathrm{a}$ and $8 \mathrm{~b}$, respectively.

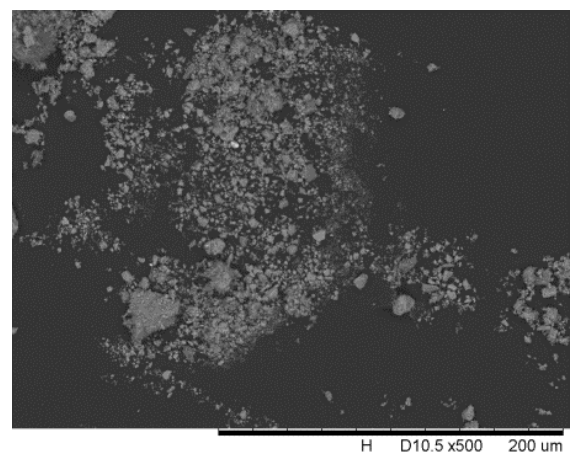

a) 


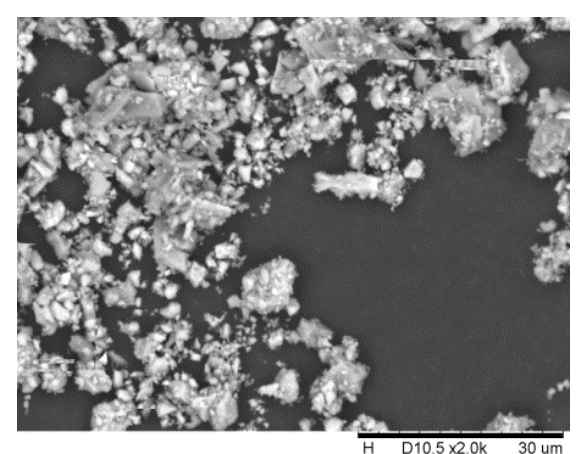

b)

Fig. 8 Scanning Electron Micrograph of Nsuta Rhodochrosite Ore utilised for the Investigation: a) $\times \mathbf{5 0 0}$

b) $\times 2.0 \mathrm{k}$

The results of SEM/EDS analyses of the Nsuta Rhodochrosite are shown in Figs 9 and 10, for Regions 1 and 2, respectively. The major elements are oxygen, manganese and carbon with minor amounts of calcium, silicon, magnesium, aluminium, fluorine and arsenic. This cluster of elements suggest the presence of silica, and carbonates/silicates of manganese, calcium and manganese that were observed in the XRD in Fig. 7.
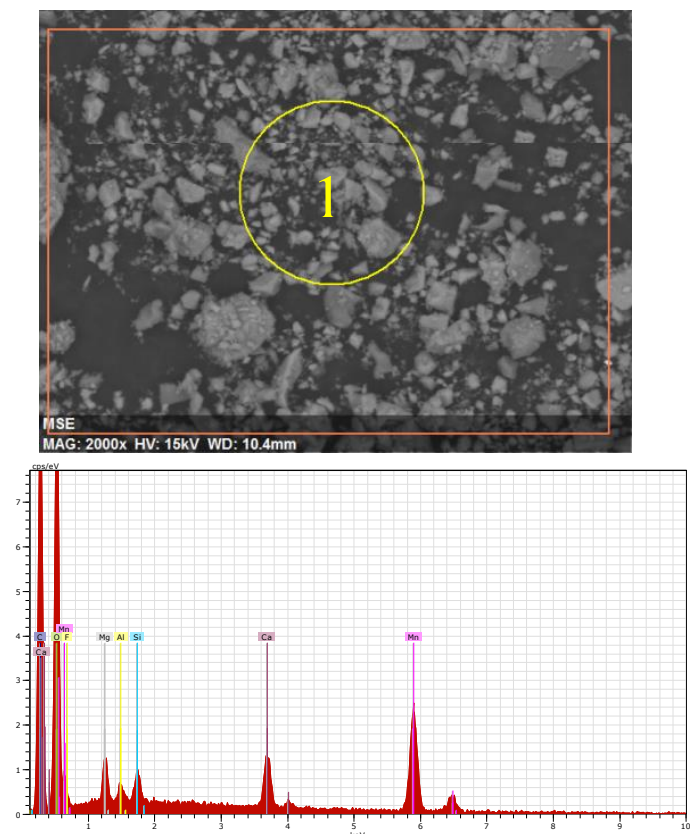

\begin{tabular}{|c|c|c|c|}
\hline Element & Atomic Number & wt \% & Atom \% \\
\hline Oxygen & 8 & 41.15 & 41.51 \\
\hline Carbon & 6 & 37.63 & 50.56 \\
\hline Manganese & 25 & 15.09 & 4.43 \\
\hline Calcium & 20 & 2.72 & 1.10 \\
\hline Fluorine & 9 & 1.22 & 1.04 \\
\hline Magnesium & 12 & 1.08 & 0.72 \\
\hline Silicon & 14 & 0.75 & 0.43 \\
\hline Aluminium & 13 & 0.35 & 0.21 \\
\hline \multicolumn{2}{|c|}{ TOTAL } & 100 & 100 \\
\hline
\end{tabular}

Fig. 9 SEM/EDS of Nsuta Rhodochrosite Ore utilised for the Investigation
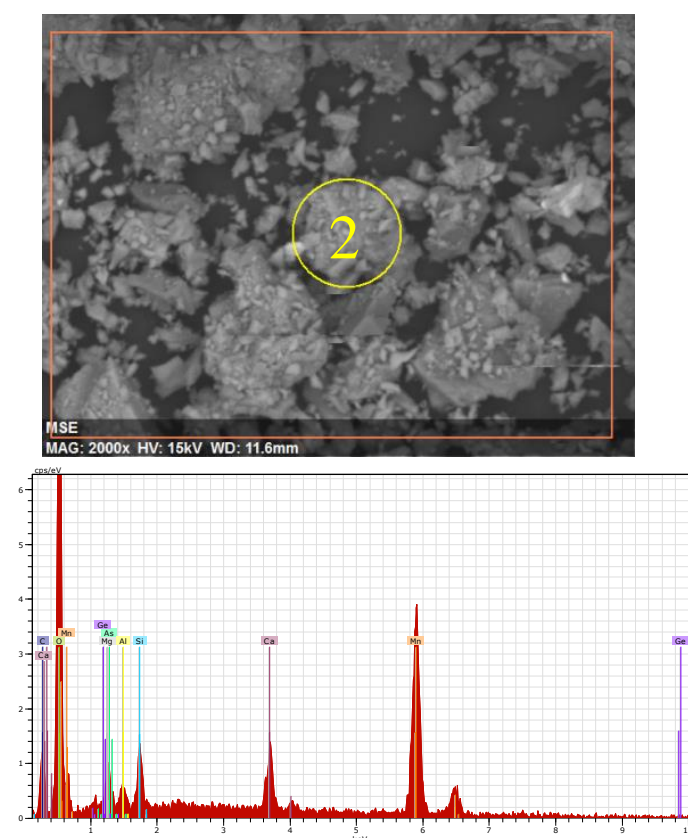

\begin{tabular}{|l|c|c|c|}
\hline Element & Atomic Number & wt \% & Atom \% \\
\hline Oxygen & 8 & 40.71 & 56.48 \\
\hline Manganese & 25 & 36.89 & 14.90 \\
\hline Carbon & 6 & 11.56 & 21.35 \\
\hline Calcium & 20 & 4.14 & 2.29 \\
\hline Silicon & 14 & 2.50 & 1.98 \\
\hline Magnesium & 12 & 1.92 & 1.75 \\
\hline Arsenic & 33 & 1.10 & 0.33 \\
\hline Aluminium & 13 & 1.07 & 0.88 \\
\hline Germanium & 32 & 0.12 & 0.04 \\
\hline \multicolumn{2}{|l}{ TOTAL } & 100 & 100 \\
\hline
\end{tabular}

Fig. 10 SEM/EDS of Nsuta Rhodochrosite Ore utilised for the Investigation (Region 2)

\subsection{Results of Calcination of Rhodochrosite Ore}

The results of temperature and weight loss measurements are shown in Tables 2 and 3 for calcination in the absence and presence of HDPE, respectively.

Table 2 Calcination of Raw Nsuta

\section{Rhodochrosite}

\begin{tabular}{|l|c|c|c|c|c|}
\hline ID & $\begin{array}{c}\text { Time } \\
(\mathbf{m i n})\end{array}$ & $\mathbf{W}_{\mathbf{1}}(\mathbf{g})$ & $\mathbf{W}_{\mathbf{2}}(\mathbf{g})$ & $\mathbf{\Delta W}(\mathbf{\%})$ & $\begin{array}{c}\mathbf{T}_{\max } \\
\left({ }^{\circ} \mathbf{C}\right)\end{array}$ \\
\hline A & 30 & 200 & 167.6 & 16.2 & 1001.2 \\
\hline B & 40 & 200 & 166.7 & 16.7 & 1339.4 \\
\hline C & 50 & 200 & 160.3 & 19.9 & 1360.1 \\
\hline D & 60 & 200 & 146.9 & 26.6 & 1366.3 \\
\hline
\end{tabular}

Table 3 Calcination of Blended Nsuta

Rhodochrosite Ore

\begin{tabular}{|l|c|c|c|c|c|c|}
\hline $\begin{array}{l}\mathbf{W}_{\text {ORE }} \\
(\mathbf{g})\end{array}$ & $\begin{array}{c}\mathbf{W}_{\text {HDPE }} \\
(\mathbf{g})\end{array}$ & $\begin{array}{c}\mathbf{W}_{\text {TOTAL }} \\
(\mathbf{g})\end{array}$ & $\begin{array}{c}\mathbf{W}_{\text {AFTER }} \\
(\mathbf{g})\end{array}$ & $\begin{array}{c}\text { Time } \\
(\mathbf{m i n})\end{array}$ & $\begin{array}{l}\Delta \mathbf{W} \\
(\mathbf{\%})\end{array}$ & $\begin{array}{c}\mathbf{T}_{\max } \\
\left({ }^{\circ} \mathbf{C}\right)\end{array}$ \\
\hline 200 & 30 & 230 & 145.4 & 60 & 36.78 & 1361 \\
\hline 200 & 40 & 240 & 144.9 & 60 & 37.00 & 1367 \\
\hline 200 & 50 & 250 & 151.2 & 60 & 34.26 & 1369 \\
\hline
\end{tabular}

In the absence of the polymer, the \%weight loss of the ore increased progressively from $16.2 \%$ to $26.6 \%$ after calcination for $30 \mathrm{~min}$ and $60 \mathrm{~min}$, respectively. Within this period the temperature in 
the fireclay crucible showed a corresponding increase from about $1001{ }^{\circ} \mathrm{C}$ to over $1366{ }^{\circ} \mathrm{C}$.

The calcined ore changes colour from grey to dark brown as shown in Fig. 11.

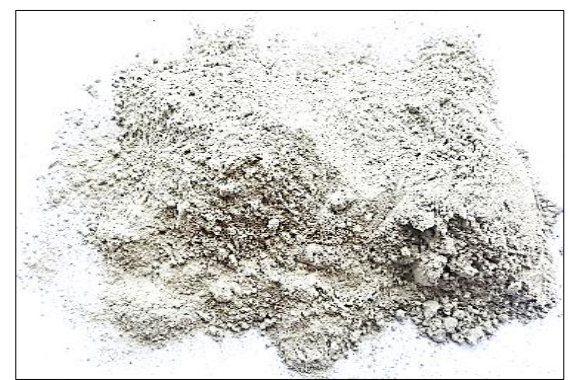

a) Original Ore

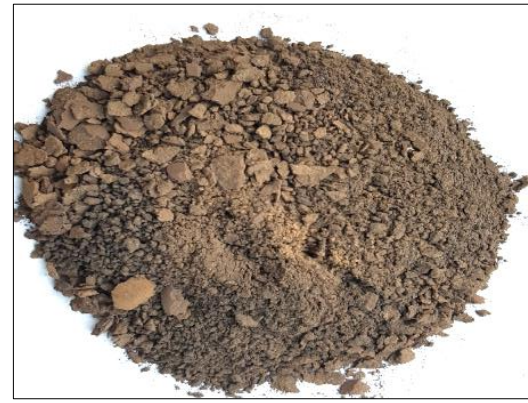

b) Calcined Sample after $30 \mathrm{~min}$

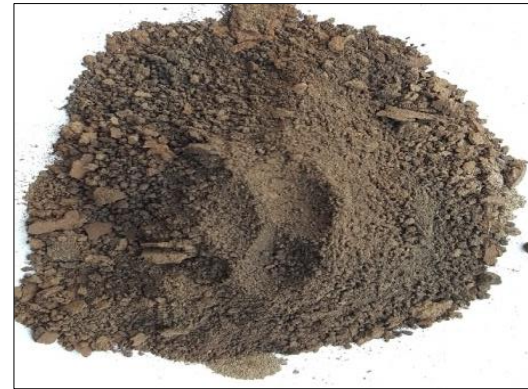

c) Calcined Sample after $\mathbf{4 0}$ min

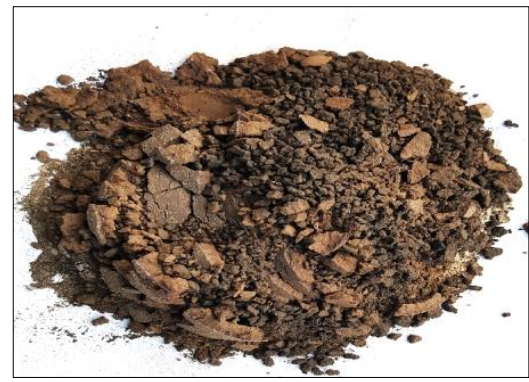

d) Calcined Sample after 50 min

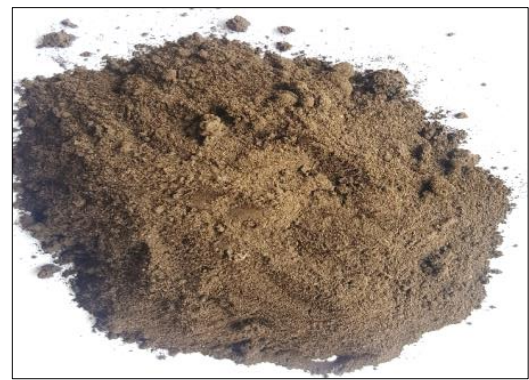

e) Calcined Sample after $60 \mathrm{~min}$

Fig. 11 Appearance of the Ore at various stages of Calcination

In the presence of the polymer, the \%weight loss of the blend increased from $36.78 \%$ to $37.00 \%$ for $30.0 \mathrm{~g}$ and $40.0 \mathrm{~g}$ HDPE addition. A possible explanation to this observation could be the extra heat supplied to the system by the thermal decomposition of the polymer, evidenced by the increase in temperature recorded in the crucible. Going beyond $40.0 \mathrm{~g}$ HDPE addition resulted in a decline in the weight loss. Examination of the calcined mass showed that the entire polymer escaped from the blend after calcination. In Table 4 , a new column is introduced showing $\%$ weight loss values based on the raw mass of the ore $(200.0$ g).

Table $4 \%$ Weight Loss against Amount of HDPE added

\begin{tabular}{|c|c|c|}
\hline $\mathbf{W}_{\text {HDPE }}(\mathbf{g})$ & $\mathbf{\Delta} \mathbf{W}^{*}(\mathbf{\%})$ & $\mathbf{T}_{\max }\left({ }^{\circ} \mathbf{C}\right)$ \\
\hline 30 & 27.3 & 1361 \\
\hline 40 & 27.55 & 1367 \\
\hline 50 & 24.4 & 1369 \\
\hline
\end{tabular}

The temperature and weight loss profiles are illustrated in Fig. 12. 


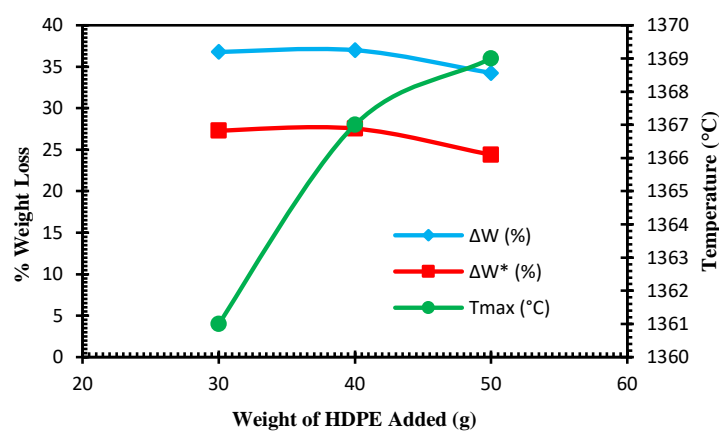

Fig. 12 Weight Loss and Temperature Profiles for Calcination of Compacts containing HDPE

Compared to the raw ore for the same calcination period of $60 \mathrm{~min}$, HDPE addition resulted in a marginal increase in the \% weight loss from $26.6 \%$ for the raw ore to $27.3 \%$ and $27.55 \%$ for $30.0 \mathrm{~g}$ and $40.0 \mathrm{~g}$ addition, respectively. Beyond this amount, it shows a decline. For a Carbonate ore of $200.0 \mathrm{~g}$ the amount of HDPE added must not exceed $40.0 \mathrm{~g}$ for effective calcination. Within this period the recorded maximum temperature increased marginally from $1361{ }^{\circ} \mathrm{C}$ to $1369^{\circ} \mathrm{C}$.

The appearance of the calcined ore in the presence of various amounts of the polymer is illustrated in Fig. 13. Obviously, each of them appears brown and there is no clear distinction between the observed colours.

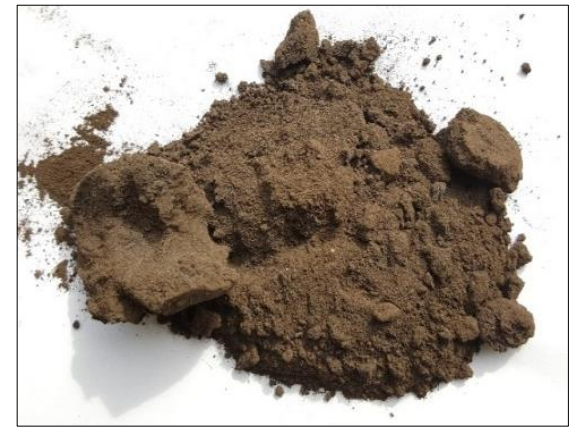

a) Calcined Blend (30 g PWS addition)

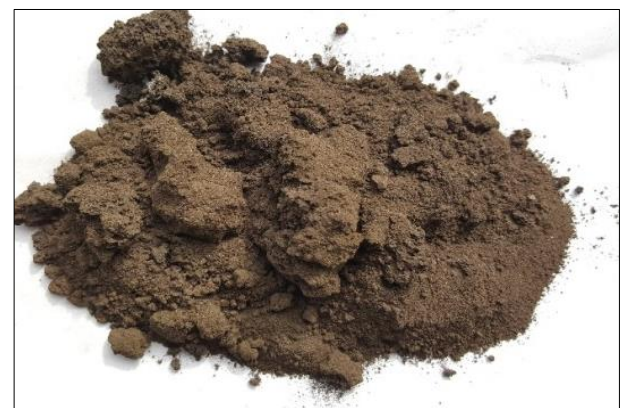

b) Calcined Blend (40 g PWS)

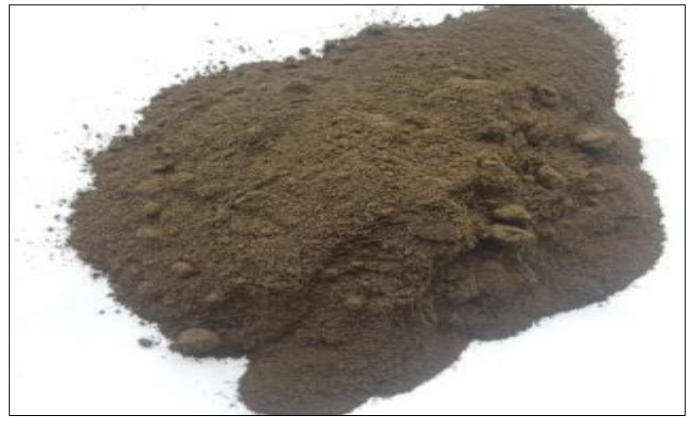

c) Calcined Blend (50 g PWS)

Fig. 13 Appearance of the Ore + HDPE Blend for various HDPE Additions for Calcination at $60 \mathrm{~min}$

Results of XRF analyses of the calcined ores are shown in Tables 5 and 6 for calcination in the absence and presence of the polymer after $60 \mathrm{~min}$ of heating. Calcination of the ore increases the $\mathrm{Mn}$ content of the ore from $39.30 \mathrm{wt} \% \mathrm{MnO}$ to 45.96 $\mathrm{wt} \% \mathrm{MnO}$ and $47.65 \mathrm{wt} \% \mathrm{MnO}$ in the absence and presence of the polymer, respectively. Although calcination of the Nsuta rhodochrosite results in an improvement in the content of the manganese content, addition of the polymer results in only a marginal improvement, consistent with the observed marginal increase in the temperature recorded in the crucible.

Table 5 XRF of Pulverised Rhodochrosite Ore after Calcination (Raw)

\begin{tabular}{llllll}
\hline Component & $\mathrm{SiO}_{2}$ & $\mathrm{Al}_{2} \mathrm{O}_{3}$ & $\mathrm{MgO}$ & $\mathrm{MnO}$ & $\mathrm{TiO}_{2}$ \\
\hline wt $\%$ & 19.20 & 8.41 & 4.52 & 45.96 & 0.22 \\
\hline Component & $\mathrm{SO}_{3}$ & $\mathrm{P}_{2} \mathrm{O}_{5}$ & $\mathrm{~V}_{2} \mathrm{O}_{5}$ & $\mathrm{CaO}$ & $\mathrm{SrO}$ \\
\hline wt $\%$ & 2.67 & 0.08 & 0.02 & 13.63 & 0.06 \\
Component & $\mathrm{Fe}_{2} \mathrm{O}_{3}$ & $\mathrm{~K}_{2} \mathrm{O}$ & \multicolumn{3}{c}{ Other oxides* } \\
wt \% & 4.09 & 1.06 & \multicolumn{3}{c}{0.08} \\
\hline *Other oxides: $\mathrm{Cr}_{2} \mathrm{O}_{3}, \mathrm{NiO}, \mathrm{BaO}, \mathrm{HfO}_{2}, \mathrm{PbO}, \mathrm{ZnO}, \mathrm{CuO}, \mathrm{WO}_{3}$
\end{tabular}

Table 6 XRF of Pulverised Rhodochrosite Ore after Calcination (with HDPE)

\begin{tabular}{llllll}
\hline Component & $\mathrm{SiO}_{2}$ & $\mathrm{Al}_{2} \mathrm{O}_{3}$ & $\mathrm{MgO}$ & $\mathrm{MnO}$ & $\mathrm{TiO}_{2}$ \\
\hline wt \% & 19.02 & 7.53 & 3.40 & 47.65 & 0.22 \\
\hline Component & $\mathrm{SO}_{3}$ & $\mathrm{P}_{2} \mathrm{O}_{5}$ & $\mathrm{~V}_{2} \mathrm{O}_{5}$ & $\mathrm{CaO}$ & $\mathrm{SrO}$ \\
\hline wt \% & 3.15 & 0.09 & 0.02 & 13.58 & 0.06 \\
Component & $\mathrm{Fe}_{2} \mathrm{O}_{3}$ & $\mathrm{~K}_{2} \mathrm{O}$ & \multicolumn{3}{c}{ Other oxides* } \\
wt \% & 4.15 & 1.04 & \multicolumn{3}{c}{0.09} \\
\hline *Other oxides: $\mathrm{Cr}_{2} \mathrm{O}_{3}, \mathrm{NiO}, \mathrm{BaO}, \mathrm{HfO}_{2}, \mathrm{PbO}, \mathrm{ZnO}, \mathrm{CuO}, \mathrm{WO}_{3}$
\end{tabular}

\subsection{Gas Measurement during Calcination of Nsuta Carbonate Ore}

The composition of the offgas $\left(\mathrm{CO}, \mathrm{CO}_{2}\right.$ and $\left.\mathrm{CH}_{4}\right)$ from the horizontal tube furnace as measured by a continuous infrared gas analyser during calcination of each of the compacts is described in this section. Fig. 14 shows the gas emission behaviour of the polymer-free compact. In the absence of HDPE the offgas from the calcination of Nsuta rhodochrosite consists predominantly of $\mathrm{CO}_{2}$ (maxima at 12.23 vol \%) and some CO (maxima at 2.71 vol \%), with virtually no traces of $\mathrm{CH}_{4}$. 


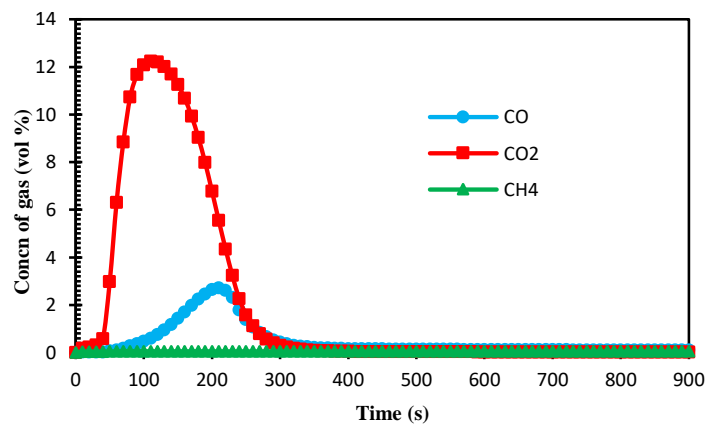

Fig. 14 Gas Emission during Calcination of Nsuta Rhodochrosite Ore in Air.

Fig. 15 represents the case where the ore was mixed with pulverised $\mathrm{HDPE}$ at $\mathrm{C} / \mathrm{O}$ of 1.0 . From Fig. 15 it is apparent that $\mathrm{CO}_{2}$ (maxima at $7.14 \mathrm{vol}$ $\%)$ is no longer the predominant gas in the composition of the offgas, as $\mathrm{CO}$ (maxima at 11.18 vol \%) now takes over and the content of $\mathrm{CO}_{2}$ declines. Significant amounts of $\mathrm{CH}_{4}$ (maxima at $2.27 \mathrm{vol} \%)$ are also observed, probably from the thermal decomposition of the polymer.

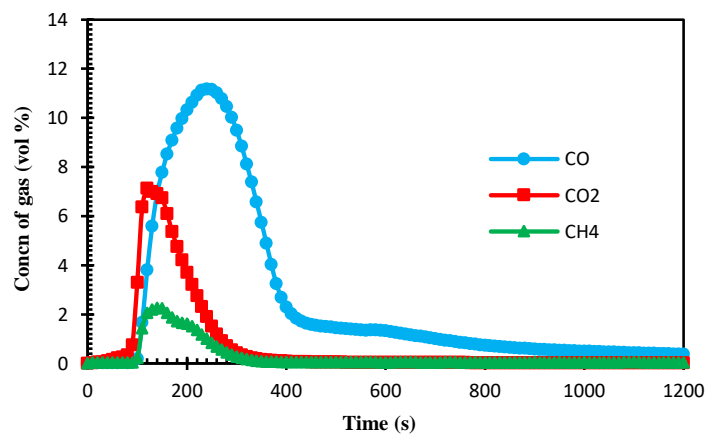

Fig. 15 Gas Generation Behaviour during the Calcination of $\mathrm{MnCO}_{3}-\mathrm{HDPE}$ compact $(\mathrm{C} / \mathrm{O}=\mathbf{1 . 0})$

From Fig. 16, increasing the $\mathrm{C} / \mathrm{O}$ ratio from 1.0 to 1.5 does not appear to change the composition of the offgas from the scenario observed for a $\mathrm{C} / \mathrm{O}$ ratio of 1.0. The observed maxima change from $7.14,11.18$ and 2.27 vol\% to $5.71,10.14$ and 2.80 vol\% for $\mathrm{CO}_{2}, \mathrm{CO}$ and $\mathrm{CH}_{4}$, respectively.

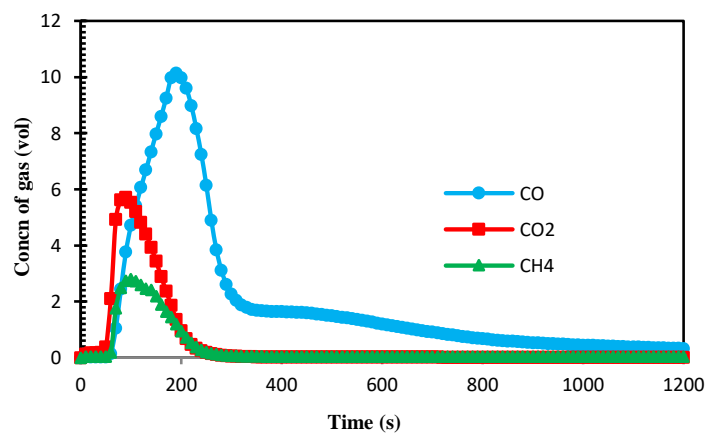

Fig. 16 Gas Generation Behaviour during the Calcination of $\mathrm{MnCO}_{3}-\mathrm{HDPE}$ compact $(\mathrm{C} / \mathrm{O}=\mathbf{1 . 5})$
At $\mathrm{C} / \mathrm{O}$ of 2.0, the corresponding maxima are 9.75 , 5.72 and 4.75 for $\mathrm{CO}, \mathrm{CO}_{2}$ and $\mathrm{CH}_{4}$, respectively, as illustrated in Fig. 17.

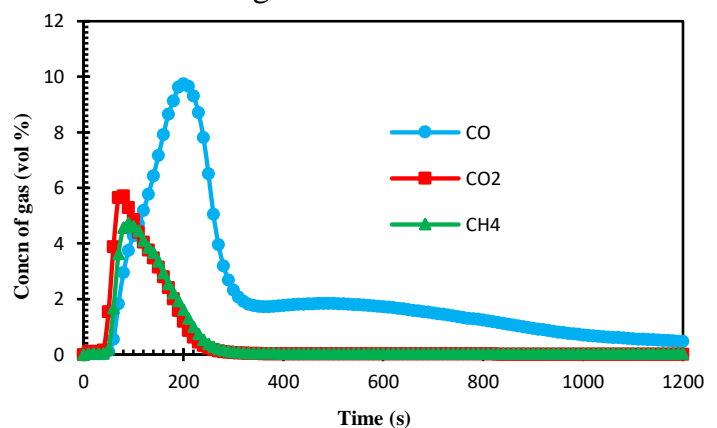

Fig. 17 Gas Generation Behaviour during the Calcination of $\mathrm{MnCO}_{3}-\mathrm{HDPE}$ compact $(\mathrm{C} / \mathrm{O}=\mathbf{2 . 0})$

\section{4 $\mathrm{CO}_{2}$ Emissions during Calcination of Nsuta Carbonate Ore}

One major concern associated with the calcination of metal carbonates is the evolution of large amounts of $\mathrm{CO}_{2}$, as is typically the case observed in cement making. The accumulated amounts (mol) of $\mathrm{CO}_{2}$ emitted in the calcination of Nsuta Rhodochrosite are plotted together and illustrated in Fig. 18. A sharp decline in the content of $\mathrm{CO}_{2}$ in the offgas (from $\sim 0.0138 \mathrm{~mol}$ to $0.0067 \mathrm{~mol}$ ) is observed when HDPE is incorporated in the compact at $\mathrm{C} / \mathrm{O}$ of 1.0. Increasing the content of $\mathrm{HDPE}$ further to $\mathrm{C} / \mathrm{O}$ ratio of 1.5 decreases the content of $\mathrm{CO}_{2}$ to $0.00472 \mathrm{~mol}$ after $15 \mathrm{~min}$ of calcination. Beyond this value of HDPE, no difference in the content of $\mathrm{CO}_{2}$ is observed, even at $\mathrm{C} / \mathrm{O}$ of 2.0 as shown in Fig. 18.

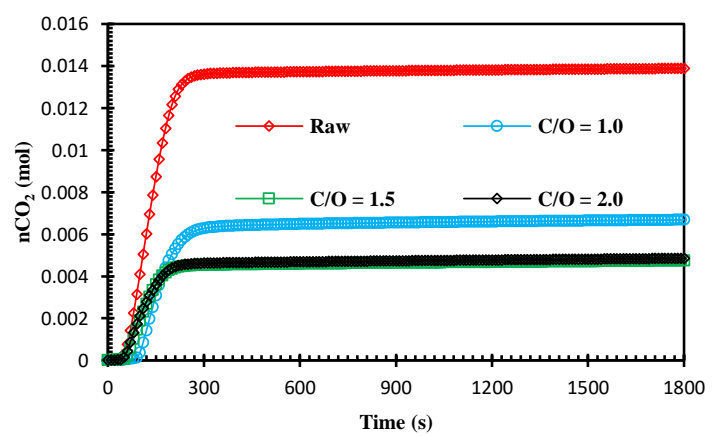

Fig. 18 Accumulated amount of $\mathrm{CO}_{2}$ evolved during calcination of various compacts of Nsuta Rhodochrosite

As elucidated earlier, in the presence of HDPE, $\mathrm{CH}_{4}$ is produced along with $\mathrm{CO}$ and $\mathrm{CO}_{2}$. $\mathrm{CO}$ takes over as the dominant gas as $\mathrm{CO}_{2}$ declines, suggesting that the $\mathrm{CH}_{4}$ produced from the thermal decomposition of HDPE is reformed by $\mathrm{CO}_{2}$ from the calcination of the ore, in accordance with equation (5). 


$$
\mathrm{CO}_{2}+\mathrm{CH}_{4}=2 \mathrm{CO}+2 \mathrm{H}_{2}
$$

From equation (5), the $\mathrm{CO}_{2}$ generated during calcination of Nsuta rhodochrosite ore can be transformed to syngas, if the ore is mixed with pulverised HDPE. A similar observation was made by Dankwah (2014) and Koshy et al. (2017) in the thermal decomposition of compacts of HDPE with reagent grade $\mathrm{MnCO}_{3}$ and Guangzhou Siderite ore $\left(\mathrm{FeCO}_{3}\right)$ from China, respectively. Evidence of the transformation of $\mathrm{CO}_{2}$ to syngas $\left(\mathrm{CO}\right.$ and $\left.\mathrm{H}_{2}\right)$ is provided by the significantly higher values of $\mathrm{CO}$ observed in the compacts containing the polymer (Fig. 19) and the significant peak of $\mathrm{H}_{2}$ observed in the gas chromatogram of Fig. 20.

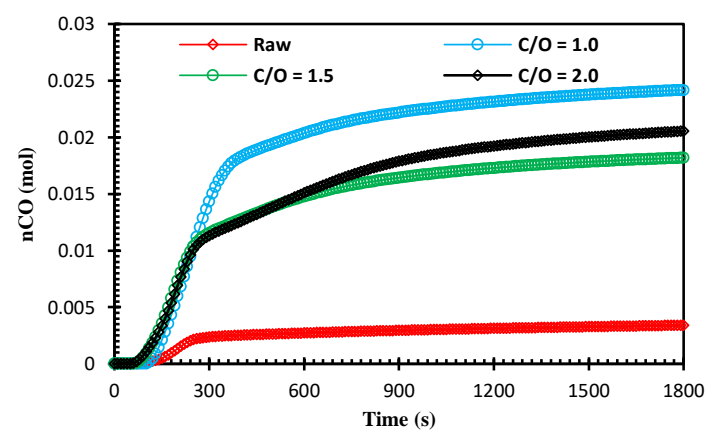

Fig. 19 Accumulated amount of CO evolved during calcination of various compacts of Nsuta Rhodochrosite

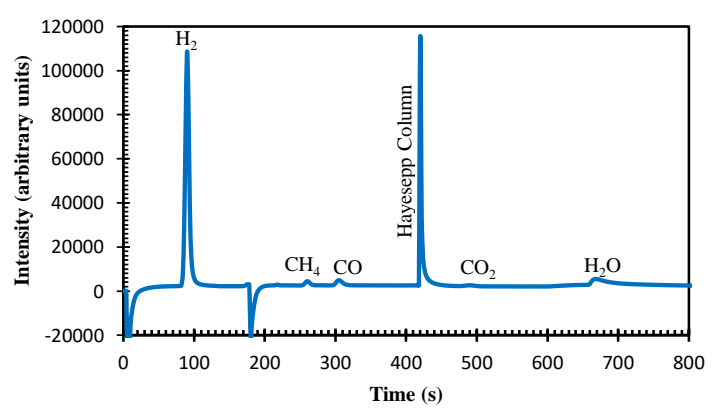

Fig. 20 Gas chromatogram obtained after calcination of $\mathrm{MnCO}_{3}-\mathrm{HDPE}$ compact $(\mathrm{C} / \mathrm{O}=\mathbf{2 . 0})$ for $15 \mathrm{~min}$ at $1200{ }^{\circ} \mathrm{C}$

\section{Conclusions}

The calcination behaviour of the Nsuta rhodochrosite ore has been investigated in the presence and absence of HDPE. The as-received ore and the calcined products were characterised by $\mathrm{XRF}, \mathrm{SEM} / \mathrm{EDS}$ and XRD analyses. The major conclusions in this investigation are:

(i) The Nsuta rhodochrosite ore consists of a mixture of manganese II carbonate $\left(\mathrm{MnCO}_{3}\right)$, silica $\left(\mathrm{SiO}_{2}\right)$, mixed transition metal carbonate of the form $\mathrm{Ca}(\mathrm{Mn}$,
$\mathrm{Mg})\left(\mathrm{CO}_{3}\right)_{2}$ and mixed metal silicate of the form $\mathrm{Ca}_{0 .} \mathrm{Mg}_{1.94} \mathrm{Si}_{2} \mathrm{O}_{6}$

(ii) Calcination of the ore resulted in visible colour changes (from grey to dark brown), along with significant changes in the mass before and after the heating process.

(iii) In the absence and presence of the polymer, measured temperatures in the crucible ranged from $1001{ }^{\circ} \mathrm{C}$ to $1366{ }^{\circ} \mathrm{C}$ and 1361 ${ }^{\circ} \mathrm{C}$ to $1369{ }^{\circ} \mathrm{C}$, respectively.

(iv) Analyses by XRF showed marginal increase in the content of Mn (measured as $\mathrm{wt} \% \mathrm{MnO})$ in the calcined ore with HDPE addition

(v) Blending the carbonate with the HDPE before heating results in significant decrease in the amount of $\mathrm{CO}_{2}$ emitted into the atmosphere. The observed decrease in $\mathrm{CO}_{2}$ emissions is accompanied by a simultaneous production of syngas $(\mathrm{CO}+$ $\mathrm{H}_{2}$ ) that can be recovered as a beneficial by-product

\section{Acknowledgements}

Part of this investigation was conducted at the School of Materials Science and Engineering, University of New South Wales, Australia. The authors are grateful to the various authorising bodies for the permission to carry out the work.

\section{References}

Amankwah, R. K. and Pickles, C. A. (2005), "Microwave calcination and sintering of manganese carbonate ore", Canadian Metallurgical Quarterly, Volume 44, No. 2, pp. 239-247.

Borgwardt, R. H. (1985), "Calcination kinetics and surface area of dispersed limestone particles", J.AIChE, Vol. 31, pp. 103-111.

Chen, Z., Song, H. S., Portillo, M., Lim, C. J., Grace, J. R. and Anthony, E. J. (2009), "Long-term calcination/carbonation cycling and thermal pretreatment for $\mathrm{CO}_{2}$ capture by limestone and dolomite", Energy Fuels, Vol. 23, pp. 1437-1444.

Criado, J. M., Gonzalez, M., Malek, J. and Ortega, A. (1995), "The effect of $\mathrm{CO}_{2}$ partial pressure on the thermal decomposition kinetics of calcium carbonate", Thermochimica Acta, vol. 254, pp. 121127.

Criado, J. M., Gonzalez, M. and Macias, M. (1987), "Influence of $\mathrm{CO}_{2}$ partial pressure on the kinetics of thermal decomposition of $\mathrm{CdCO}_{3}$ ", Thermochimica Acta, Vol. 113, pp. 31-38.

Criado, J. M., Gonzalez, F. and Gonzalez, M. (1982), 
"Influence of the $\mathrm{CO}_{2}$ pressure on the kinetics of thermal decomposition of manganese carbonate", Journal of Thermal Analysis, Vol. 24, p. 59-65.

Dankwah, J. R. (2014), "Simultaneous Production of Syngas and $\mathrm{MnO}$ from $\mathrm{MnCO}_{3}$-Waste Polymer Composite Pellets", International Journal of Scientific and Technology Research (IJSTR), Vol. 3, No. 2, pp. 321-325.

Dankwah, J. R. and Asamoah D. N. (2013), "Utilisation of Postconsumer Plastics in Prereduction of Higher Manganese Oxides in Ferromanganese Process", Ironmaking and Steelmaking, 40(2), pp. 138-146.

Dankwah, J. R., Koshy, P., O'Kane, P. and Sahajwalla, V. (2012), "Reduction of $\mathrm{FeO}$ in EAF Steelmaking Slag by Blends of Metallurgical Coke and End-of-Life Tyres", Steel Research International, 83(8), pp. 766774.

Dankwah, J. R., Koshy, P., Saha-Chaudhury, N. M., O'Kane, P., Skidmore, C., Knights, D. and Sahajwalla, V. (2011), "Reduction of FeO in EAF Steelmaking Slag by Blends of Metallurgical Coke and Waste Plastics", ISIJ Int., 51(3), pp. 498-507.

Kesse, G. O. (1985). The Mineral and Rock Resources of Ghana, A. A. Balkema Publishers, Rotterdam, $610 \mathrm{pp}$.

Kim, H. T. and Kwon, H. B. (1998), "Kinetic study of limestone calcination and sulfation reaction under AFBC environment", Environ. Eng. Res., Vol. 3, pp. 105-113.

Koshy, P., Dankwah, J. B., Dankwah, J. and Dankwah, J. R. (2018), "Calcination Behaviour of Guizhou Siderite Ore and its Amenability to Reduction by Waste Polymers", Ghana Journal of Technology, Vol. 3, No. 1, pp. 63-68.

Li, Z., Shen, X., Feng, X., Wang, P. and Wu, Z. (2005), "Non-isothermal kinetics studies on the thermal decomposition of zinc hydroxide carbonate", Thermochimica Acta, Vol. 438, pp. 102-106.

O'Shaughnessy, P., Kim, J.K. and Lee, B.W., (2004), "The smelting of manganese carbonate ore". In Proceedings: Tenth International Ferroalloys Congress, INFACON X, Cape Town, South Africa, Vol. 1, pp. 223-230.

Samtani, M., Dollimore, D., and Alexander, K. S. (2002), "Comparison of dolomite decomposition kinetics with related carbonates and the effect of procedural variables on its kinetic parameters", Thermochimic. Acta., Vol. 392-393, pp. 135-145.

Telfer, M., Zhong, Z., Xu, Y., Li, D., Zhang, M. and Zhang, D. K. (2000), "An experimental study of calcination of South Australian Caroline limestone", Dev. Chem. Eng. Mineral Process., Vol. 8, pp. 245267.

Wang, Y., Lin, S. and Suzuki, Y. (2007), "Study of limestone calcination with $\mathrm{CO}_{2}$ capture: Decomposition behaviour in a $\mathrm{CO}_{2}$ atmosphere", Energy Fuels, Vol. 21, pp. 3317-3321.

Yamada, S., Tsukumo, E. and Koga, N. (2009), "Influence of evolved gases on the thermal decomposition of zinc carbonate hydroxide evaluated by controlled rate evolved gas analysis coupled with TG", Journal of Thermal Analysis and Calorimetry, Vol. 95, no. 2, pp. 489-493.

Yamaguchi, J., Sawada, Y., Sakurai, O., Uematsu, K., Mizutani, N. and Kato, M. (1980), “Thermal decomposition of cerussite $\left(\mathrm{PbCO}_{3}\right)$ in carbon dioxide atmosphere (0-50 ATM)", Thermochimica Acta, Vol. 35, pp. 307-313.

\section{Authors}

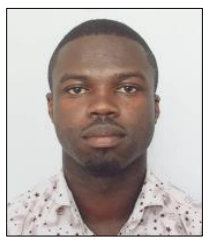

Kwaku Ohene Nimako is an MSc student in Minerals Engineering at the university of Mines and Technology (UMaT), Tarkwa. He completed his BSc degree from the University of Cape Coast His current research area includes upgrading of low grade manganese ores using end-of-life polymers as reductants.

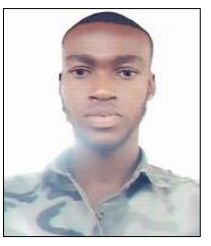

technology

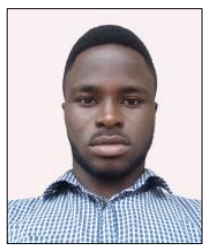

Andrew Dwumfour is a National Service person at AngloGold Ashanti (Iduapriem Mine), Tarkwa. He completed his BSc degree at the University of Mines and Technology. His current research interest is in hydrometallurgy, pyrometallurgy, waste management, environmental engineering and sustainable materials processing and

and sustainable materials processing and technology.

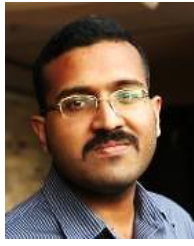

Pramod Koshy is currently a Senior Research Fellow at the School of Materials Science and Engineering, UNSW, Australia. He holds his Ph.D. from the School of Materials Science and Engineering, UNSW, Australia. He His main areas of research include photocatalytic materials, hightemperature metal/ceramic interfaces, and utilization of waste materials.

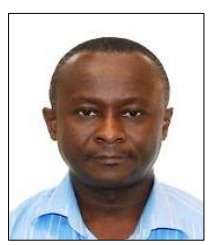

James R. Dankwah is an Associate Professor and Head of Minerals Engineering Department at the University of Mines and Technology, UMaT-Tarkwa. $\mathrm{He}$ obtained his $\mathrm{PhD}$ from the School of Materials Science and Engineering, UNSW-Australia, MSc (Process Metallurgy) from the Norwegian University of Science and Technology and BSc (Metallurgical Engineering) from the Kwame Nkrumah University of Science and Technology, Kumasi, Ghana. He is a Fellow of the West African Institute of Mining, Metallurgy and Petroleum (WAIMM). His current research areas include iron and steelmaking, high-temperature metallurgical processes, utilisation of waste polymers in metal extraction processes and recycling agricultural waste into building blocks materials for affordable housing for the rural folks. 